\title{
The Research of Corporate Governance, Industrial Over-investment and Corporate Over-investment
}

\author{
Su-yuan Tian ${ }^{1}$, Ping Ye ${ }^{2}$, Ke Gao ${ }^{1}$ \\ ${ }^{1}$ The School of Finance and Taxation, Central University of Finance and Economics, Beijing, P. R. China \\ ${ }^{2}$ The School of Business, Central University of Finance and Economics, Beijing, P. R. China
}

Email address:

502406907@qq.com (Su-yuan Tian),yping810@21cn.com (Ping Ye), gkfly@126.com (Ke Gao)

\section{To cite this article:}

Su-yuan Tian, Ping Ye, Ke Gao. The Research of Corporate Governance, Industrial Over-investment and Corporate Over-investment. Journal of Investment and Management. Vol. 6, No. 1, 2017, pp. 56-59. doi: 10.11648/j.jim.20170601.19

Received: May 7, 2017; Accepted: May 30, 2017; Published: June 6, 2017

\begin{abstract}
The corporate governance of listed companies is the focus and hot spot of financial research in recent years. Using a sample of A-share listed firms in China for the period 2003-2015, the paper investigates corporate governance on the relationship between industrial over-investment and the over-investment. The results show that: (1) The information transparency restrains the positive relationship between industrial over-investment and the next period of over-investment. (2) Major shareholder increases the positive relationship between industrial over-investment and the over-investment.
\end{abstract}

Keywords: Over-investment, Industrial Over-investment, Information Transparency, Major Shareholder

\section{Introduction}

"Infectious effects" is the focus and hot spot of financial research in recent years. With the deepening of the division of labor between enterprises, business connections are becoming closer [1]. The economic decision-making behavior among managers has a "convergence effect". Investment activities are the strategic means for enterprises to create value. However, because of the problems of agency and information asymmetry in the real market economy and financial market, the corporate managers invest the net present value of negative items to build an empire [2]. Does the corporate governance influence the relationship between industrial over-investment and the over-investment?

In order to answer the issue, the paper use the data from 2003-2015 to study the corporate governance on the relationship between industrial over-investment and the over-investment. The results show that: (1) The information transparency restrains the positive relationship between industrial over-investment and the next period of over-investment. (2) Major shareholder increases the positive relationship between industrial over-investment and the over-investment.

The rest of this paper is organized as follows. Second 2 is theoretical hypothesis. Second 3 is the research design.
Second 4 is the empirical result and analysis. Second 5 is the conclusion and inspiration.

\section{Theoretical Hypothesis}

Capital market influences real economy based on information transmission theory. A transparent market environment is the key to invest for managers. Based on the information transparency and corporate governance mechanism, the paper analyzes the two aspects to study the effect of information transparency on the relationship between industrial over-investment and the next period of Over-investment: (1) Information transparency reflects the ability of listed companies to disclose information. High information transparency of the company reacts a lot of company factors. Accordingly, the traded information of the company comes into the stock price information a lot. Investors are more likely to identify incompetent managers in high information transparency of the company. Managers are cautious to the investment in the company's investment decision-making. The supervision effect of the listed company managers curb the over-investment. (2) Shareholders and investors monitors the company's operations easily in high 
information transparency company [3]. At the same time, shareholders and investors can compare the profitability of the situation with other companies in the industry and evaluate the management of managers [4]. High information transparency helps managers carefully operating listed companies to curb their excessive investment. Based on this, the following assumptions are made:

H1: The information transparency restrains the positive relationship between industrial over-investment and the next period of over-investment.

The controlling shareholders lead to the agency problem between the major shareholders and the minority shareholders. The existence of controlling shareholders exacerbates the over- investment behavior of listed companies [5]. The proportion of major shareholders rises, and the discourse of big shareholders becomes great. Large shareholders have more power to misappropriate the company's assets. At the same time, it is difficult for small shareholders to supervise major shareholders. What's more, compared with the blind decisions of major shareholders, the collective decision-making can not choose bad program easily [6]. Based on above reasons, the paper takes the hypothesis:

H2: Major shareholder increases the positive relationship between industrial over-investment and the over-investment.

\section{Research Design}

\section{A. Sample Selection and Data Sources}

The following samples are processed as follows: (1) excluding data missing samples. (2) excluding samples of financial listed companies. (3) Winsorizing 1\% and $99 \%$ of the continuous variables. Finally, 9916 observations were made on industrial over-investment. All the data comes from CSMAR database.

\section{B. Model Design and Variable Definition}

Drawing lessons from previous literature [7], the paper mainly tests corporate governance to the relationship between industrial Over-investment and the next period of Over-investment behavior through the following fixed effect model (1) and model (2).

$$
\begin{gathered}
\text { Oinv }_{i, t}=\alpha+\beta \text { Oinv }_{-i, t-1} * \text { Abacc }+\gamma \text { Abacc }+\lambda \text { Oinv }_{-i, t-1}+\varphi \text { control variables }_{i, t-1}+\varepsilon_{i, t-1}+\delta_{t-1}+\theta_{t-1} \\
\text { Oinv }_{i, t}=\alpha+\beta \text { Oinv }_{-i, t} * \text { Tophold }+\gamma \text { Tophold }+\lambda \text { Oinv }_{-i, t}+\varphi \text { control variables }_{i, t}+\varepsilon_{i, t}+\delta_{t}+\theta_{t}
\end{gathered}
$$

Including, Oinv $_{\mathrm{i}, \mathrm{t}}$ represents the over-investment level of the listed corporate in the year. Oinv $\mathrm{i}_{-\mathrm{i}}$ is expressed as industrial over-investment. Abacc means information transparency. Tophold means Major shareholder. Control variables is the corporate own financial variable. $\varepsilon$ and $\delta$ represents time and industry effects, and $\theta$ represents a fixed effect. Specific variables are as follows:

a. Over-investment

$$
\begin{aligned}
& \text { Inv }_{i, t}=\alpha_{0}+\alpha_{1} Q_{i, t-1}+\alpha_{2} \text { Lev }_{i, t-1}+\alpha_{3} \text { Cash }_{i, t-1}+\alpha_{4} \text { Age }_{i, t-1}+\alpha_{5} \text { Size }_{i, t-1} \\
& +\alpha_{6} \operatorname{Return}_{i, t-1}+\alpha_{7} \operatorname{Inv}_{i, t-1}+\sum \text { industry }+\sum \text { year }+\varepsilon_{i, t}
\end{aligned}
$$

For the measurement of Over-investment, the paper uses the model of previous literature to estimate the over-investment level of the firm using the above model (3) [8].

b. Industrial Over-investment

$\mathrm{Oinv}_{-\mathrm{i}}$ represents the average of the excess investment level of the same industry corporate (excluding itself).

c. Information Transparency

$$
\begin{gathered}
\frac{T A_{i, t}}{A S S E T_{i, t-1}}=\alpha_{0} \times \frac{1}{A S S E T_{i, t-1}}+\beta_{1} \frac{\Delta S A L E S_{\mathrm{i}, t}}{A S S E T_{i, t-1}}+\beta_{2} \frac{P P E_{\mathrm{i}, t}}{A S S E T_{i, t-1}}+\varepsilon_{i, t} \\
\operatorname{DISACC}_{i, t}=\frac{T A_{i, t}}{A S S E T_{i, t-1}}-\left(\hat{\alpha_{0}} \times \frac{1}{A S S E T_{i, t-1}}+\hat{\beta}_{1} \times \frac{\Delta S A L E S_{i, t}-\Delta R E C E I V E A B L E S_{i, t}}{A S S E T_{i, t-1}}+\hat{\beta}_{2} \times \frac{P P E_{i, t}}{A S S E T_{i, t-1}}\right)
\end{gathered}
$$

For the measurement of information transparency, the paper uses the model of previous literature to estimate the information transparency level of the firm [9]. The models are above model (4) and model (5).

d. Major Shareholder

Proportion of major shareholders in listed companies.

f. Other Control Variables
According to previous literature [10], the control variables are as follows. There are corporate size, financial leverage level, free cash flow cash, stock annual rate of return, growth opportunity, minority interests rate and management fee rate. In addition, we control the annual and industry effects respectively. Specific methods are as table 1: 
Table 1. Description of the main variables.

\begin{tabular}{llll}
\hline Variable category & Variable symbol & variable name & calculation methods \\
\hline Explained variable & Oinv $_{\mathrm{i}}$ & Over-investment & (Calculation method above the text) \\
Explanatory variables & Oinv $_{\mathrm{i}}$ & Industrial Over-investment & (Calculation method above the text) \\
& Abacc & information transparency & (Calculation method above the text) \\
& Tophold & major shareholder & (Calculation method above the text) \\
& Lev & financial leverage level & Total liabilities / total assets \\
& Cash & free cash flow cash & (Net operating cash flow - normal investment level) / total assets \\
Control variable & Size & corporate size & The natural logarithm of the total assets \\
& Ret & stock annual rate of return & Stock annual rate of return \\
& Exp & Management fee rate & Management fee rate \\
& Growth & growth Opportunity & Sales revenue growth rate \\
& Mino & Minority interests rate & Minority interests / owners' equity \\
\hline
\end{tabular}

\section{Empirical Results and Analysis}

\section{A. Descriptive Statistics}

There are 9916 data in the table 2. Table 2 shows that the mean of over-investment is 0.079 , and the median is 0.072 . The mean of the industry over-investment level is 0.077 , and the median is 0.082 . The mean of Abacc is 0.085 , and the median is 0.054 . The mean of major shareholder is 0.372 , and the median is 0.357 . The above results show that there are significant over-investment levels of listed companies in China.

Table 2. Major variables and Descriptive statistics.

\begin{tabular}{lllllll}
\hline variable & N & Mean & Max & Min & Median & Std \\
\hline Oinv $_{\mathrm{i}}$ & 9,916 & 0.079 & 0.223 & 0 & 0.072 & 0.045 \\
Oinv $_{\text {i }}$ & 9,916 & 0.077 & 0.223 & 0 & 0.082 & 0.020 \\
Abacc & 9,916 & 0.085 & 0.700 & 0.001 & 0.054 & 0.108 \\
Tophold & 9,916 & 0.372 & 0.781 & 0.060 & 0.357 & 0.157 \\
Lev & 9,916 & 0.486 & 1.622 & 0.0470 & 0.489 & 0.222 \\
Cash & 9,916 & 0.170 & 0.727 & 0.002 & 0.137 & 0.125 \\
Size & 9,916 & 21.91 & 26.57 & 18.83 & 21.77 & 1.279 \\
Ret & 9,916 & 0.326 & 3.643 & -0.729 & 0.112 & 0.803 \\
Exp & 9,916 & 0.048 & 0.208 & 0.003 & 0.042 & 0.033 \\
Growth & 9,916 & 0.209 & 4.406 & -0.707 & 0.119 & 0.589 \\
Mino & 9,916 & 0.077 & 0.486 & -0.045 & 0.038 & 0.101 \\
\hline
\end{tabular}

\section{B. Empirical Analysis}

In order to test the influence of information transparency on the relationship between industrial over-investment and the next period of over-investment, we add the Abacc and Oinv $_{-1}{ }^{*} A b a c c$ cross terms in the model, and the regression results are shown in table 3 . The results of (1) and (2) in Table 3 test the effect of information transparency on the over-investment of the peers and the over-investment of the next year. In Table 3 (1) has no variable financial index control of listed companies. The coefficient of the industrial over-investment and the next period of over-investment is 0.418 , and its statistically significant is at $1 \%$ level. The coefficient of $\mathrm{Oinv}_{-\mathrm{i}}{ }^{*}$ Abacc and the next period of over-investment is -0.192 , and its statistically significant is at $1 \%$ level. (2) joins the financial index of listed company control variables. The coefficient of the industrial over-investment and the next period of over-investment is 0.382 , and its statistically significant is at $1 \%$ level. The coefficient of Oinv $_{-i}{ }^{*}$ Abacc and the next period of over-investment is -0.295 , and its statistically significant is at
$1 \%$ level. The above results show that the information transparency can restrain the positive relationship between industrial over-investment and the next period of over-investment. Supporting the "hypothesis 1".

Table 3. Information Transparency, Industrial Over-investment and Over-investment.

\begin{tabular}{|c|c|c|}
\hline & (1) $\operatorname{Oinv}_{i}$ & (2) Oinv \\
\hline $\mathrm{Oinv}_{-\mathrm{i}}$ & $\begin{array}{l}0.418 * * * \\
(8.74)\end{array}$ & $\begin{array}{l}0.382 * * * \\
(8.27)\end{array}$ \\
\hline $\mathrm{Oinv}_{-\mathrm{i}} * \mathrm{Abacc}$ & $\begin{array}{l}-0.192 * * * \\
(-3.11)\end{array}$ & $\begin{array}{l}-0.295^{* * *} \\
(-4.24)\end{array}$ \\
\hline Abacc & $\begin{array}{l}0.010^{* * *} \\
(5.01)\end{array}$ & $\begin{array}{l}0.021^{* * *} \\
(7.26)\end{array}$ \\
\hline Cash & & $\begin{array}{l}0.093 * * * \\
(35.19)\end{array}$ \\
\hline Growth & & $\begin{array}{l}-0.000 \\
(-0.80)\end{array}$ \\
\hline Ret & & $\begin{array}{l}0.014^{* * * *} \\
(26.28)\end{array}$ \\
\hline Size & & $\begin{array}{l}0.005^{* * *} \\
(17.86)\end{array}$ \\
\hline Lev & & $\begin{array}{l}-0.003 * * * \\
(-10.35)\end{array}$ \\
\hline Exp & & $\begin{array}{l}0.004 * * * \\
(10.31)\end{array}$ \\
\hline Mino & & $\begin{array}{l}-0.030 * * * \\
(-9.25)\end{array}$ \\
\hline Constant & $\begin{array}{l}0.022 * * * \\
(6.61)\end{array}$ & $\begin{array}{l}-0.098 * * * \\
(-14.91)\end{array}$ \\
\hline year & Control & Control \\
\hline industry & Control & Control \\
\hline Observations & 9,916 & 9,916 \\
\hline r2_a & 0.198 & 0.317 \\
\hline $\mathrm{F}^{-}$ & 129.9 & 181.2 \\
\hline
\end{tabular}

In order to test the influence of the major shareholder on the relationship between industrial over-investment and over-investment, we add the Tophold and Oinv-i $_{-i}^{*}$ Tophold cross terms in the model, and the regression results are shown in table 4. The results of (1) and (2) in Table 4 test the effect of major shareholder on the industrial over-investment and the over-investment. In Table 4 (1) has no variable financial control index of listed companies. The coefficient of the industrial over-investment and over-investment is 0.304 , and its statistically significant is at $1 \%$ level. The coefficient of Oinv $_{-i}{ }^{*}$ Tophold and the over-investment is 0.007 , and its statistically significant is at $1 \%$ level. (2) joins the financial control index of listed company. The coefficient of the 
industrial over-investment and the over-investment is 0.275 , and its statistically significant is at $1 \%$ level. The coefficient of Oinv $_{-i}{ }^{*}$ Tophold and the over-investment is 0.007 , and its statistically significant is at $1 \%$ level. The above results show that major shareholder can increase the relationship between industrial over-investment and over-investment. Supporting the "hypothesis 2".

Table 4. Major Shareholder, Industrial Over-investment and Over-investment.

\begin{tabular}{|c|c|c|}
\hline & (1) $\operatorname{Oinv}_{i}$ & (2) Oinv $_{i}$ \\
\hline $\mathrm{Oinv}_{-\mathrm{i}}$ & $\begin{array}{l}0.304^{* * *} \\
(5.03)\end{array}$ & $\begin{array}{l}0.275 * * * \\
(4.52)\end{array}$ \\
\hline Oinv $_{-\mathrm{i}}$ *Tophold & $\begin{array}{l}0.007 * * * \\
(7.15)\end{array}$ & $\begin{array}{l}0.007 * * * \\
(6.61)\end{array}$ \\
\hline Tophold & $\begin{array}{l}-0.000^{* *} \\
(-2.17)\end{array}$ & $\begin{array}{l}-0.000 * * * \\
(-2.95)\end{array}$ \\
\hline Cash & & $\begin{array}{l}0.071 * * * \\
(26.26)\end{array}$ \\
\hline Growth & & $\begin{array}{l}-0.001 \\
(-0.92)\end{array}$ \\
\hline Ret & & $\begin{array}{l}-0.002 * * * \\
(-4.27)\end{array}$ \\
\hline Size & & $\begin{array}{l}0.004 * * * \\
(13.57)\end{array}$ \\
\hline Lev & & $\begin{array}{l}-0.002 * * * \\
(-6.61)\end{array}$ \\
\hline Exp & & $\begin{array}{l}0.005 * * * \\
(2.97)\end{array}$ \\
\hline Mino & & $\begin{array}{l}-0.030 * * * \\
(-9.07)\end{array}$ \\
\hline Constant & $\begin{array}{l}0.021^{* * * *} \\
(5.12)\end{array}$ & $\begin{array}{l}-0.055^{* * *} \\
(-7.44)\end{array}$ \\
\hline year & Control & Control \\
\hline industry & Control & Control \\
\hline Observations & 9,916 & 9,916 \\
\hline r2_a & 0.206 & 0.251 \\
\hline $\mathrm{F}^{-}$ & 150.0 & 143.8 \\
\hline
\end{tabular}

\section{Robustness Test}

Draw lessons from previous literature to measure the median of the enterprise investment in the industry [11]. The paper uses the median of the over-investment to measure the industrial over-investment. The model is regressed, and the research conclusions unchanged.

\section{Conclusion and Suggestion}

The paper chooses the perspective of corporate governance to study Over-investment's "Infectious effects". Based on the data from 2003 to 2015, it mainly studies the corporate governance on the relationship between industrial over-investment and the over-investment. The results show that: (1) The information transparency restrains the relationship between industrial over-investment and the next period of over-investment. (2) Major shareholder increases the positive relationship between industrial over-investment and the over-investment. The results have an important meaning on the industry.

For the listed companies in the industry, the industrial common negative information pass a false impression of the misleading signal, and the false signal leads to the listed company managers to take the wrong response. The paper shows that the listed companies have "convergence effect" and "herd behavior", which leads to the spread of negative news in the industry. Revealing the negative effects of the industry's infectious effects helps managers to identify industry information and promote the development of listed companies in the industry.

\section{References}

[1] Huang Jun, Chen Xinyuan, Zhang Tianshu. Research on the contagion effect of corporate performance, World management, 2013, (3): 111-118.

[2] Jensen M C. Agency Costs of Free Cash Flow, Corporate Finance and Takeovers, American Economic Review, 1986,76(2):323 329.

[3] Parrino R. CEO Turnover and Outside Succession: A Cross sectional Analysis [J]. Journal of Financial Economics, 1997, 46 (2): 165 197

[4] Zhao Chunxiang, Zhang Dunli. Research on the Relationship between Managerial Power and Enterprise Investment from the Perspective of Market Competition [J]. Accounting Research, 2013, (10): 67-74+97.

[5] Yu Honghai, Xu Longbing, Chen Baizhu. Ultimate Controlling Shareholder Control and Free Cash Flow Over-investment [J]. Economic Research, 2010, (08): 103-114.

[6] Li Xiaorong, Dong Hongye, Zhang Ruijun. Does Corporate CEO Power Influence Bank Lending Decisions? [J]. Finance and Trade Economics, 2015, (07): 81-95.

[7] Foucault T, Fresard L. Learning from Peers' Stock Prices and Corporate Investment [J]. Journal of Financial Economics, 2013, 111(3): 554-577.

[8] Richardson S. Over-investment of Free-cash Flow [J]. Review of Accounting Studies, 2006, 91(2): 159 189.

[9] Dechow P M, Sloan R G. Sweeney A. P. Detecting Earnings Management [J]. The Accounting Review, 1995, 70: 193-225

[10] Shen Huihui, Yu Peng. Wu Liansheng. State Owned Shares, Environmental Uncertainty and Investment Efficiency [J]. Economic Research, 2012, (7): 113-126.

[11] Zhang Dunli, Jiang Xinfeng. Manager's Power, Property Right and Enterprise Investment [J]. Journal of Zhongnan University of Economics and Law, 2016, (5): 82-90. 